\title{
Economic basis of evaluation of land resources and their capitalization
}

\author{
Mahsudov Muhammadbek Dilshodbek Ugli ${ }^{1 *}$, Bobomurodova Shokhsanam Shavkat Gizi ${ }^{2}$ \\ Tashkent Institute of Irrigation and Agricultural Mechanization Engineers, Uzbekistan 1,2 \\ muhammadbek.maxsudov@bk.ru ${ }^{1}$ sh.bobomurodov@tiiame.uz ${ }^{2}$
}

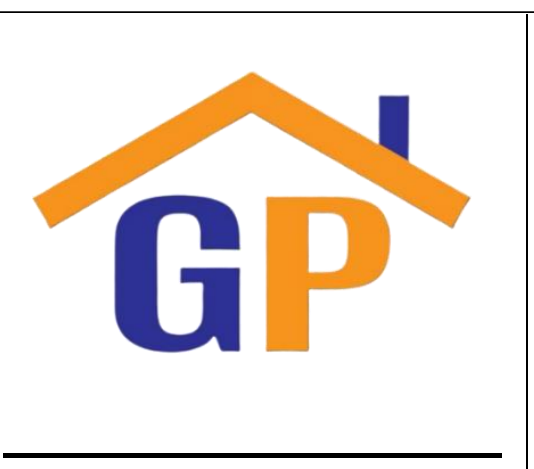

Article History

Received on 13 November 2019

$1^{\text {st }}$ Revision on 21 December 2019

$2^{\text {nd }}$ Revision on 2 December 2019

$3^{\text {rd }}$ Revision on 8 December 2019

Accepted on 16 December 2019

\begin{abstract}
Purpose: This article covers the issues of land resources evaluation and development of proposed recommendations in improving the processes of capitalization, examining the economic
\end{abstract} foundations of their capitalization.

Research methodology: Land valuation is of significant economic and social importance. From its data, it is widely used in solving various issues of economic sectors, including land tax, determining the amounts of rent on land plots, planning the yields of agricultural crops, creating land and in general, solving all issues that are closely related to land use.

Results: New methods of capitalizing on land use have been proposed.

Limitations: Capitalization issues are carried out on the basis of decisions of the executive power. In the introduction of experiments into practice, government decisions are relied on.

Contribution: Modern methods of assessing land resources lead to sustainable economic growth.

Keywords: Land resources, Valuation, Rent, Capital, Privatization

How to cite: Ugli M. M. D., \& Qizi, B. S. S. (2020). Economic basis of evaluation of land resources and their capitalization. International Journal of Financial, Accounting, and Management, 1(2),

101-103.

https://doi.org/10.35912/ijfam.v1i2.95

\section{Introduction}

The relevance of the issue of land valuation and their capitalization in the implementation of economic reforms carried out in the Republic, the radical reform of land relations, the introduction of the principles of market economy into land use relations is further increasing. At the same time, in practice, cases of the application of error in the types of land valuation in the solution of these or that tasks also ruin. This indicates that land valuation, goals and objectives have not been adequately studied, which at the state, regional, local level. has led to gross errors in the resolution of issues related to land valuation. The economic basis of land valuation and land capitalization became known how relevant it was with the transition of the country's economy, including land use, to the market economy. In-depth scientific and practical justification and rationalization of the evaluation methods used and now introduced should be made acceptable.

\section{Literature review and hypotheses development}

Initially, the evaluation activities were carried out in the middle of the XIX century in Great Britain, in 1861 year by the king of Great Britain to the surveyrs (visual arts). surveyor-land surveyor) appeared within the framework of their profession at the time when the profession was given the right 
to self-regulation, and the Royal Charter Institute of surveyors was established. At the moment, this organization provides real estate-related specialists (architects, agents in operations with Real Estate, Appraisers, etc.) the unification is the largest professional organization in the world and has more than 70 thousand members from a hundred countries of the world in its ranks [2].

The legal status of land plots is an important factor that determines their value.In the current conditions of Uzbekistan, land is considered one of the most complex objects of economic assessment in the structure of real estate. This is explained by the peculiarity of this object and the development of the land market in our country.Until now, the fact that our land resources have not been privatized is due to the fact that we still have a system in the Soviet system of land use. The land market is not organized, the land becomes a resource if it is privatized and is valued as capital.

When land resources are privatized, they become capitallazation is of great importance in the development of the market economy. Unfortunately, so far this evaluation process remains unregulated. Much more subjectivity is still preserved in this matter. The solution of this issue is of great importance.

The international assessment bodies are developed by the International Standards Committee (IVSC) on assessment bodies, which unites the professional organizations of appraisers of more than 50 countries of the world. Neither in the US nor in Europe, "norms" or "measures"are considered an absolute set of laws. Therefore, one of the main objectives of IVSC is to achieve compliance between the National measures of the assessment and the andases corresponding to the needs of the international community.

\section{Research methodology}

According to the state of January 1, 2018, the Republic has a total of 376,8 thousand trees per year, including 8,4 thousand trees per year in the Kitab District of Kashkadarya region.

In developed countries of the world, various methodological approaches to the assessment of real estate are used. For example, in the practice of England on property valuation, five methods are common: benchmarking,investment,profit, residual, contractor. In the practice of us appraisers usually takes precedence over three methods: cost, comparative and revenue. In Uzbekistan, real estate valuation is carried out on the basis of cost (balance sheet), comparative, (comparison, market) and income approaches, as in the US [1].

In our republic, the demand for Real Estate Valuation Services appeared from the first days of transition to a market economy [4]. The increase in the privatization of state real estate, including the privatization of land plots. The activities of the assessment of real estate objects carried out in the past years necessitate the development of it on a strong methodological basis, taking into account the peculiarities of the reform model of the economy of the Republic and the many years of experience of evaluation work in foreign countries.

Along with the training of specialists in property valuation in the Republic, it is necessary to redevelop educational programs in the field of valuation of various objects of property. At the same time, there are not enough specialists who have been conducting evaluation activities so far, and it is necessary to increase the number of educational literature on "evaluation of real estate", organization of courses, peculiarities of the approaches formed in Uzbekistan, evaluation of land resources. To this day, our lands are not valued as private property. Now the issues of privatization of our lands are rising. This is due to the need to evaluate the land as capital.

\section{Results and discussions}

The legal landscape of land plots is an important factor that determines their value. In the current conditions of Uzbekistan, land is considered one of the most complex objects of economic assessment in the structure of real estate. This is explained by the peculiarity of this object and the development of the land market in our country. The difference of the land plot from other types of real estate was determined by the following characteristics: 
- land is a natural resource, unlike other types of real estate objects, it is not possible to freely it reproduce;

- during the evaluation, it is always necessary to take into account the possibility (agricultural and forest lands participate as a means of production of raw materials resources and food products, which are necessary for almost all sectors of the economy) of multi-purpose use of the land, both as a basic means of production (the land is of latitude for the placement of various real estate objects) and as a breadth for socio-economic development

- unlike other real estate objects, the concepts of physical and functional wear and tear, as well as depreciation, do not apply to the value of land plots, since the land plot is not limited period of exploitation;

\section{Conclusion and suggestions}

1. In order for us to organize the process of valuation of our lands as capital, it is necessary to develop independent valuation structures with the participation of capital of leading foreign valuation companies in the Republic of Uzbekistan. In order for us to privatize our land resources, first of all, it is necessary to develop a valuation methodology.

2. A distinctive feature of the reforms carried out in our republic is the programming and gradual implementation of privatization. This property determines the conditions for the gradual development of land value assessment work. When considering the problems of improving the assessment of land resources, it is necessary to develop a system of self-regulation of valuation activities. Unfortunately, significant results have been achieved so far on the practical development of the system of selfregulation of assessment activities in the Republic. The task of the "Society of appraisers of Uzbekistan" in the field of this work is great.

3. It is necessary to develop the land market, to increase the number of objects and subjects involved in its circulation, to expand the range of services provided by the market infrastructure, to develop a competitive environment in it and, on this to improve its functioning basis.

\section{Limitation and study forward}

The research work aims at improving the methods of implementation of land resource appraisal based on the capitalisation method in the future and ensuring that this method is put into practice.

\section{Acknowledgement}

We express our gratitude to the Tashkent Institute of irrigation and agricultural engineers for their comprehensive assistance in carrying out the research work.

\section{References}

Altiev A.S., Mahsudov M.D. (2019). Methods of forecasting and management of land fund diversification in local areas. International Journal of Recent Technology and Engineering, 8 (3), 403-411. DOI: 10.35940/ijrte.C1086.1083S19.

Mahsudov M.D. (2019). Диверсификация землепользования является фактором развития. Monograph. LAP Lambert Academic Publishing, 71-72.

Babajanov A.R., Mahsudov M.D. (2019) Diversification of land fund in the district. Monograph. LAP Lambert Academic Publishing, 77-78.

Altiev A.S. (2019). Regulation of land relations - an important condition of development strategy. Asian Journal Multidimensional Research, 8 (5), 344-350. DOI: 10.5958/22784853.2019.00211.8. 